\title{
Occurrence of anthracnose pathogen races and resistance genes in common bean across 30 years in Brazil
}

\author{
Pollyana Priscila Schuertz Paulino ${ }^{1}$ (D) Maria Celeste Gonçalves-Vidigal ${ }^{1, *}$ (D), \\ Mariana Vaz Bisneta ${ }^{1}$, , Pedro Soares Vidigal Filho $^{1}{ }^{\mathbb{D}}$, Maria Paula Barion \\ Alves Nunes ${ }^{1}{ }^{\mathbb{D}}$, Larissa Fernanda Sega Xavier $^{1}{ }^{\mathbb{D}}$, Vanusa Silva Ramos \\ Martins $^{1}\left(\mathbb{D}\right.$ and Giselly Figueiredo Lacanallo ${ }^{1}$
}

\footnotetext{
${ }^{1}$ Departamento de Agronomia, Universidade Estadual de Maringá, Avenida Colombo, 5790, Maringá, PR, Brazil, CEP 87020-270. *Corresponding author, E-mail: mcgvidigal@uem.br
}

\section{ABSTRACT}

Anthracnose caused by Colletotrichum lindemuthianum is one of the most critical diseases in the common bean (Phaseolus vulgaris L.). The characterization and localization of pathogenic fungal races are essential for understanding pathogen population dynamics and recommending strategies to develop resistant cultivars. As resistant genotypes are the most economical and ecologically safe means of controlling plant diseases, there have been efforts to characterize resistance genes in common bean. Several studies using a system of 12 differential bean cultivars have been carried out to monitor anthracnose since 1991, reporting the constant appearance of new fungal races. C. lindemuthianum shows high virulence diversity. The objective of the present study was to review the relationship between $C$. lindemuthianum races and the common bean pathogenic processes involved in the risk of developing anthracnose disease. As a result, 89 races occurred in Brazil, wherein 73,65 , and 81 of $C$. lindemuthianum are the most frequent. Furthermore, we built a map with the anthracnose resistance loci, molecular markers, and their respective physical position. The accessibility to the genomes and sequencing technologies permits molecular markers for marker-assisted selection applied to anthracnose-resistant cultivars. This study could be used as a reference for future resistance mapping studies and as a guide for selecting resistance loci in breeding programs aiming to develop common bean cultivars with durable anthracnose resistance.

Keywords: Resistance and virulence index, resistant cultivars, cultivar durability, durable resistance, pyramiding resistance genes, genomic regions. 


\section{INTRODUCTION}

Common bean (Phaseolus vulgaris L.) is one of the primary sources of carbohydrates, proteins, vitamins, and minerals worldwide (Carvalho et al., 2012; Perilla, Cirino, Ruas, Pavan, \& Gonçalves, 2015). Anthracnose (ANT) is caused by the fungus Colletotrichum lindemuthianum (Sacc. \& Magn.) Bri. \& Cav. It is considered one of the most severe diseases that affect bean productivity. In fact, under favorable conditions, anthracnose can reduce bean production by up to $100 \%$ (Singh \& Schwartz, 2010; Campa, Rodríguez-Suárez, Giraldez, \& Ferreira, 2014). The most effective approach to protect bean plants from anthracnose pathogens is the use of resistant cultivars (Pacheco, Berrouet, Yepes, Sánchez, \& Montoya, 2014). However, resistant cultivars are harmed by the recurrent appearance of new virulence phenotypes, usually referred to as races, of $C$. lindemuthianum. The best strategy for breeding programs to increase the durability of cultivar resistance is to characterize predominant races in the main growing regions and pyramiding anthracnose resistance genes from both Andean and Mesoamerican origins in new cultivars (Kelly, Gepts, Miklas, \& Coyne, 2003).

Brazil is the third biggest common bean producer worldwide, mainly of Carioca and Preto's types that belong to the Mesoamerican group (Companhia nacional de abastecimento, 2019; Food and Agriculture Organization, 2019). The most significant variability of $C$. lindemuthianum races is found in Brazil. The diversity found in common bean and $C$. lindemuthianum suggest coevolution, and both species are divided into two distinct groups (Andean and Mesoamerican) (PastorCorrales, 2004). Andean races of the anthracnose pathogen are usually isolated from large-seeded beans that belong to the Andean gene pool. Mesoamerican races are often isolated from small- or medium-seeded beans belonging to the Mesoamerican gene pool. However, Mesoamerican races are compatible with Mesoamerican and Andean beans and they exhibit greater virulence and genetic diversity than the Andean races (Pastor-Corrales, 2004).

Studies at the molecular level have been conducted based on sequence data that indicate that the common bean is of Mesoamerican ancestry and originated in Mexico (Schmutz et al., 2014). Later expansion to South America resulted in developing two significant and distinct common bean gene pools: Mesoamerican and Andean (Bitocchi et al., 2017). Moreover, Andean cultivars tend to be more resistant to Mesoamerican races of the pathogen, which have high variability and aggressiveness (Pastor-Corrales, 2004). Hence, one strategy to reduce the susceptibility of common bean plants and develop cultivars with durable resistance is pyramiding resistance genes from Andean and Mesoamerican pools (Melotto \& Kelly, 2000). Previous studies revealed intra-race variability based on sequencing of the ITS1, 5.8S and ITS2 regions on pathogen population structure of C. lindemuthianum (Coêlho, Gonçalves-Vidigal, Vidigal Filho, Franzon, \& Martins, 2020). The authors suggested independent evolution of specific virulence types such as, races $0,2,31,72,73,75,83$, and 89 in different geographic regions and they noticed that races $0,2,31,72,73,75,83$, and 89 exhibited intra-race molecular variability.

The present study aimed to investigate $C$. lindemuthianum occurrences in Brazil in the last thirty years as described in the literature. In addition, we built a common bean in silico map with genomic regions containing anthracnose resistance genes and the respective molecular markers linked to these regions. 


\section{GENETIC STUDIES WITH ANTHRACNOSE IN COMMON BEAN}

This study reviews C. lindemuthianum races in Brazil from 1991 to 2021 using the methodology proposed by Pastor-Corrales (1991). Furthermore, we sought the anthracnose resistance genes already described in the literature to facilitate common bean breeding for resistance to anthracnose races identified in Brazil. Once molecular markers are essential for marker-assisted selection in breeding programs, we also searched for molecular markers linked to the anthracnose resistance loci.

\section{Phenotyping data using differential cultivars}

The group of differential cultivars contains accessions from Mesoamerican and Andean origin. In this system, each cultivar receives a value of $2^{n-1}$, where 2 represents the number of reaction classes considered (resistant or susceptible) and " $n$ " is a function of the order of the differentiators ( $n=1$ to 12). Table 1 presents the differential cultivars, including their anthracnose resistance genes and the binary system used for naming races of $C$. lindemuthianum.

Table 1. Performance of the common bean differential cultivars to Colletotrichum lindemuthianum proposed by Pastor-Corrales (1991) using the binary system.

\begin{tabular}{|c|c|c|c|c|}
\hline $\begin{array}{c}\text { Differential } \\
\text { Cultivars }\end{array}$ & $\begin{array}{l}\text { Gene } \\
\text { Pool }^{1}\end{array}$ & Resistant Genes & $\begin{array}{l}\text { Binary } \\
\text { Value }\end{array}$ & $\begin{array}{c}\text { Numeric Value } \\
\qquad\left(2^{n-1}\right)\end{array}$ \\
\hline Michelite & MA & Co-11 & $2^{0}$ & 1 \\
\hline Michigan Dark Red & $A$ & Co-1 & $2^{1}$ & 2 \\
\hline \multicolumn{5}{|l|}{ Kidney } \\
\hline Perry Marrow & $A$ & $\mathrm{Co}-1^{3}$ & $2^{2}$ & 4 \\
\hline Cornell 49242 & MA & Co-2 & $2^{3}$ & 8 \\
\hline Widusa & $A$ & $\mathrm{Co}-1^{5}$ & $2^{4}$ & 16 \\
\hline Kaboon & $A$ & $\mathrm{Co}-1^{2}$ & $2^{5}$ & 32 \\
\hline Mexico 222 & MA & Co-3 & $2^{6}$ & 64 \\
\hline PI 207262 & MA & $\mathrm{Co}-3^{3} ; \mathrm{CO}^{3} 4^{3}$ & $2^{7}$ & 128 \\
\hline TO & MA & Co-4 & $2^{8}$ & 256 \\
\hline TU & MA & Co-5 & $2^{9}$ & 512 \\
\hline AB 136 & MA & Co-6; co-8 & $2^{10}$ & 1024 \\
\hline G 2333 & MA & $\mathrm{Co}-3^{5} ; \mathrm{Co}^{-} 4^{2} ; \mathrm{Co}^{-5^{2}}$ & $2^{11}$ & 2048 \\
\hline
\end{tabular}

${ }^{1} \mathrm{MA}$ : Mesoamerican gene pool; A: Andean gene pool.

The terminology of the race consists of the sum of the numerical values of susceptible differential cultivars. For example, anthracnose race 73 overcomes the resistance of Michelite [1], Cornell 49-242 [8], and Mexico 222 [64]; the numerical values of the susceptible cultivars are added $[1+8+64=73]$, and the isolate is 
characterized as race 73 . The standardization of the system allowed the comparison of data from different research groups and understanding of the population dynamics of the pathogen (Pastor-Corrales, 1991). Figure 1 illustrates the anthracnose symptoms include necrotic or depressed lesions, of various colors and shapes, in leaf, hypocotyl and pods.
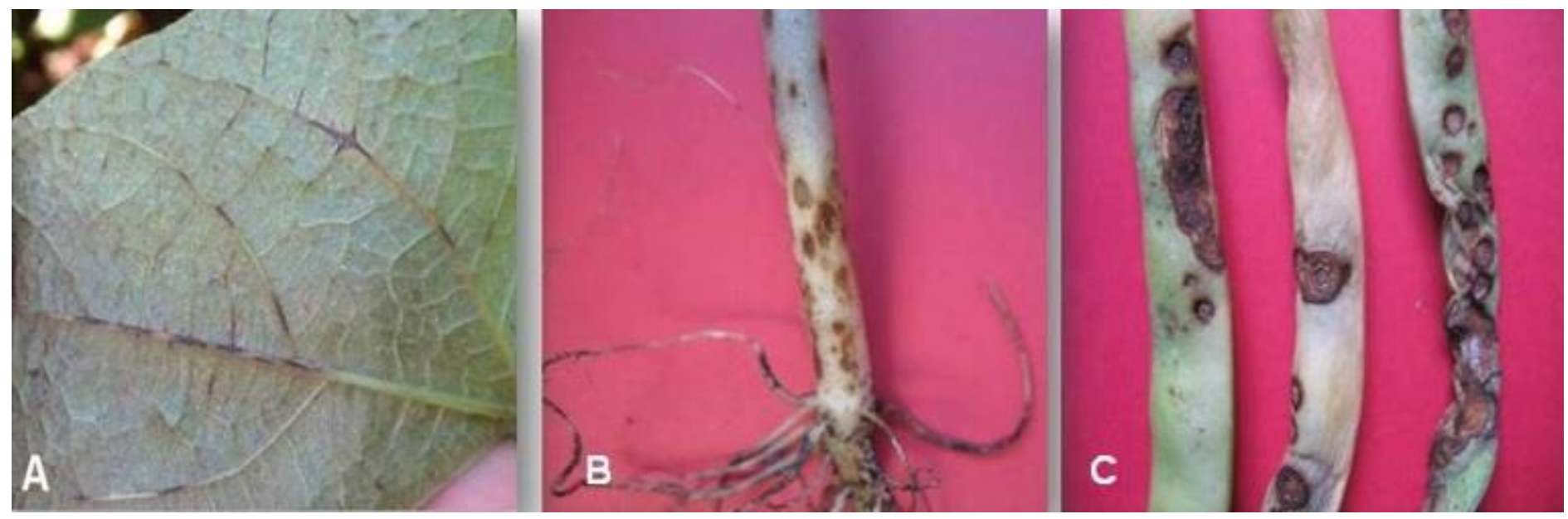

Figure 1. Anthracnose symptoms. A - Leaf; B - Hypocotyl; C - Pods.

Source: Nupagri, UEM.

Resistance index (RI) and virulence index (VI) values for 12 differential cultivars were expressed as percentages (Vidigal Filho, Gonçalves-Vidigal, Kelly, \& Kirk, 2007). A virulence index (VI) was calculated for each race identified in Brazil by:

Where:

$$
V I=\frac{S \times 100}{C}
$$

$\mathrm{VI}=$ virulence index;

$\mathrm{S}=$ total number of differential cultivars that was susceptible to that race;

$\mathrm{C}=$ total number of differential cultivars (12).

For instance, race 2 overcomes only the resistance of Michigan Dark Red Kidney; therefore, the $\mathrm{VI}$ of race 2 is $V I=\frac{1 \times 100}{12}=8.3 \%$. A resistance index (RI) for each of the 12 differential cultivars was calculated for the races reported in Brazil from 1991 to 2021 . The RI values were computed by:

Where:

$$
R I=\frac{R \times 100}{T}
$$

$\mathrm{RI}=$ resistance index;

$\mathrm{R}=$ total number of races that each differential cultivar was resistant;

$\mathrm{T}=$ total number of races of $C$. lindemuthianum evaluated (89 races).

\section{In silico data}

An integrated map was built using the anthracnose resistance loci and molecular markers linked to these loci using the last version of the G 19833 common bean reference genome sequence (version 2.1 available at www.phytozome.org). To identify the physical position of ANT resistance loci in the reference genome, we performed a nucleotide essential local alignment search tool 
(BLASTn) search using the sequence of the molecular marker (linked to the ANT resistance gene) described in the literature. Then, we built a map with the anthracnose resistance loci and molecular marker and $C$. lindemuthianum races using the MapChart software (Voorrips, 2002).

\section{Characterization of Colletotrichum lindemuthianum races in Brazil}

Several studies aiming to understand differences in the virulence and population structure of the fungus $C$. lindemuthianum have been conducted. A total of 89 races were characterized using the differential cultivars in Brazil from 1991 to 2021. The presence of many different races reveals the significant variability of this pathogen. This variability could be attributed to the fact that Brazil is one of the largest common bean growers in the world (Food and Agriculture Organization [FAO], 2019). Races of Colletotrichum lindemuthianum characterized in each State of Brazil from 1991 to 2021 are illustrated in Table 2.

The States of Paraná, Santa Catarina, and Goiás showed more races identified in the country. Paraná has the highest virulence diversity concerning $C$. lindemuthianum; 65 races are present (73.03\% of all races found in Brazil). This state was also Brazil's largest producer of common bean in 2018/2019, with a mean yield of 1,551 kg ha-1 (Companhia Nacional de Abastecimento [CONAB], 2019). The wide distribution of $C$. lindemuthianum in this region facilitates the pathogen's adaptation to various climatic conditions.

Table 2. Races of Colletotrichum lindemuthianum characterized in Brazil from 1991 to 2021.

\begin{tabular}{|c|c|c|c|}
\hline States & $\begin{array}{l}\text { № of } \\
\text { races }\end{array}$ & Races & References \\
\hline Bahia & 7 & $\begin{array}{l}23,65,71,81,87,101 \\
\text { and } 119 .\end{array}$ & $\begin{array}{l}\text { Rava, Purchio and Sartorato } \\
\text { (1994); Mesquita, Paula Júnior, } \\
\text { Moreira, and Barros (1998); } \\
\text { Alzate-Marin and Sartorato } \\
\text { (2004). }\end{array}$ \\
\hline $\begin{array}{l}\text { Distrito } \\
\text { Federal }\end{array}$ & 7 & $\begin{array}{l}65,69,73,81,87,101 \\
\text { and } 119 .\end{array}$ & $\begin{array}{l}\text { Rava et al. (1994); Alzate-Marin } \\
\text { and Sartorato (2004). }\end{array}$ \\
\hline $\begin{array}{l}\text { Espirito } \\
\text { Santo }\end{array}$ & 9 & $\begin{array}{l}64,65,67,72,73,75,79 \\
87 \text { and } 585 .\end{array}$ & $\begin{array}{l}\text { Rava et al. (1994); Mesquita et } \\
\text { al. (1998); Alzate-Marin and } \\
\text { Sartorato (2004). }\end{array}$ \\
\hline Goiás & 18 & $\begin{array}{l}8,23,65,69,71,73,77, \\
81,83,87,89,97,109, \\
117,119,125,127 \text { and } \\
593 .\end{array}$ & $\begin{array}{l}\text { Rava et al. (1994); Mesquita et } \\
\text { al. (1998); Alzate-Marin \& } \\
\text { Sartorato (2004); Talamini et al. } \\
\text { (2004). }\end{array}$ \\
\hline Mato Grosso & 11 & $\begin{array}{l}1,8,9,10,24,64,65,72 \\
73,81 \text { and } 114\end{array}$ & $\begin{array}{l}\text { Gonçalves-Vidigal, Nunes, Cruz, } \\
\text { Sousa and Vidigal Filho (2009); } \\
\text { Felipin-Azevedo et al. (2014). }\end{array}$ \\
\hline $\begin{array}{l}\text { Mato Grosso } \\
\text { do Sul }\end{array}$ & 3 & 89, 339 and 343 . & Rava et al. (1994). \\
\hline Minas Gerais & 15 & $\begin{array}{l}0,8,64,65,66,69,73, \\
81,83,85,87,89,119, \\
337 \text { and } 585 .\end{array}$ & $\begin{array}{l}\text { Rava et al. (1994); Talamini et } \\
\text { al. (2004); Alzate-Marin and } \\
\text { Sartorato (2004); Silva, Souza, } \\
\text { Sartorato, \& Ishikawa (2007); }\end{array}$ \\
\hline
\end{tabular}


Pinto, Pereira, Mota, Ishikawa and Souza (2012).

\begin{tabular}{|c|c|c|c|}
\hline Paraíba & 2 & 65 and 73. & $\begin{array}{l}\text { Rava et al. (1994); Mesquita et } \\
\text { al. (1998); Alzate-Marin and } \\
\text { Sartorato (2004). }\end{array}$ \\
\hline Paraná & 65 & $\begin{array}{l}0,1,2,3,7,8,9,10,11, \\
17,24,25,26,27,31,52, \\
55,64,65,67,69,72,73, \\
75,77,79,81,82,83,85, \\
87,89,90,91,93,95,96, \\
97,101,102,105,109, \\
123,127,137,193,249, \\
259,283,287,320,321, \\
337,339,343,345,346, \\
351,453,457,465,475, \\
585,1,601 \text { and } 1,609 .\end{array}$ & $\begin{array}{l}\text { Rava et al. (1994); Mesquita et } \\
\text { al. (1998); Carneiro (1999); } \\
\text { Thomazella, Gonçalves-Vidigal, } \\
\text { Vidigal Filho, Nunes and Vida, } \\
\text { (2002); Alzate-Marin and } \\
\text { Sartorato (2004); Sansigolo, } \\
\text { Gonçalves-Vidigal, Vidigal Filho, } \\
\text { Gonela and Kvitschal (2008); } \\
\text { Barcelos, Souza and Silva, } \\
\text { (2011); Uchôa et al. (2015); } \\
\text { Xavier et al. (2018). }\end{array}$ \\
\hline Pernambuco & 20 & $\begin{array}{l}2,3,7,8,9,10,23,64, \\
65,72,73,75,81,85,87, \\
89,117,119,139 \text { and } \\
331 .\end{array}$ & $\begin{array}{l}\text { Rava et al. (1994); Alzate-Marin } \\
\text { and Sartorato (2004); } \\
\text { Martiniano-Souza et al. (2021). }\end{array}$ \\
\hline $\begin{array}{ll}\text { Rio } & \text { de } \\
\text { Janeiro }\end{array}$ & 1 & 73 & $\begin{array}{l}\text { Rava et al. (1994); Alzate-Marin } \\
\text { and Sartorato (2004). }\end{array}$ \\
\hline $\begin{array}{l}\text { Rio Grande } \\
\text { do Sul }\end{array}$ & 17 & $\begin{array}{l}5,17,23,31,55,64,65 \\
67,69,72,73,77,81,83, \\
87,97 \text { and } 453 .\end{array}$ & $\begin{array}{l}\text { Rava et al. (1994); Mesquita et } \\
\text { al. (1998); Somavilla \& Prestes } \\
\text { (1999); Alzate-Marin and } \\
\text { Sartorato (2004). }\end{array}$ \\
\hline $\begin{array}{l}\text { Santa } \\
\text { Catarina }\end{array}$ & 22 & $\begin{array}{l}7,55,65,67,73,75,77, \\
81,83,86,87,89,95, \\
101,103,105,109,111, \\
121,217,249 \text { and } 581 .\end{array}$ & $\begin{array}{l}\text { Balardin, Jarosz and Kelly } \\
\text { (1990); Rava et al. (1994); } \\
\text { Alzate-Marin and Sartorato } \\
\text { (2004); Gonçalves-Vidigal, } \\
\text { Thomazella, Vidigal Filho, } \\
\text { Kvitschal and Elias (2008). }\end{array}$ \\
\hline São Paulo & 15 & $\begin{array}{l}4,23,31,38,55,65,73 \\
81,83,85,87,89,95,127 \\
\text { and } 351 .\end{array}$ & $\begin{array}{l}\text { Talamini et al. (2004); Silva et } \\
\text { al., (2007); Ribeiro et al. } 2016 .\end{array}$ \\
\hline Sergipe & 1 & 89 & $\begin{array}{l}\text { Rava et al. (1994); Alzate-Marin } \\
\text { and Sartorato (2004). }\end{array}$ \\
\hline Brazil $^{1}$ & 26 & $\begin{array}{l}0,8,9,55,64,65,67,69, \\
71,72,73,81,91,83,85, \\
87,89,91,93,97,321, \\
329,337,479,513,529, \\
535 \text { and } 593 \text {. }\end{array}$ & $\begin{array}{l}\text { Silva et al. (2005); Ishikawa, } \\
\text { Souza, Silva and Freire (2008); } \\
\text { Wendland, Abud, Melo, Pereira } \\
\text { and Díaz (2011). }\end{array}$ \\
\hline
\end{tabular}

Santa Catarina ranks second in virulence diversity, with 22 races $(24.72 \%$ in the country). Pinto et al. (2012) analyzed 74 C. lindemuthianum isolates and reported the occurrence of six races, with races 65 and 81 being predominant. The state of Pernambuco ranked third in virulence with 20 races of $C$. lindemuthianum characterized. In Goias state 18 races were characterized, while in the Rio Grande 
do Sul were identified 15 races. Studies have reported the importance of races 65 , 73, 81, and 87 in Brazil, and these races have been detected in almost all states for more than 20 years (Alzate-Marin \& Sartorato, 2004; Talamini et al., 2004; Silva et al., 2007; Ribeiro et al., 2016). Race 73 is the most frequently found over the years, present in 13 of the 14 states examined. Race 65 is currently in 12 states and race 81 is present in 11 states.

Previous studies by Balardin, Jarosz, and Kelly (1997) showed only races 7, 65, and 73 to be widely distributed. Somavilla \& Prestes (1999) characterized 100 isolates from different Brazilian regions. Only races 81, 65, 73, and 321 were present in all investigated areas. In 1990, races 7 and 73 were first identified in Michigan, USA, and 73 persevered for over 29 years (Kelly, Awale, \& Wiersma, 2020). The appearance of race 109 suggests that the resistance allele $\mathrm{Co}-1^{2}$ from the Kaboon cultivar had been overcome (Awale, Bornowski, Wright, Varner, \& Kelly, 2018). Therefore, monitoring the appearance of new races is essential for breeding programs and the adoption of different resistance genes for pyramiding as a breeding strategy for durable resistance.

Balardin and Kelly (1998) reported that the simultaneous production of Andean and Mesoamerican beans in the same region might allow for the selection of broader virulence in $C$. lindemuthianum, with some races being highly virulent toward genotypes from both gene pools. This fact would explain the capacity of some races to adapt to more than one region; for example, races 65 , and 73 , which are widely spread across crop regions. In addition, to coevolution between a pathogen and a host, seed handling is a determining factor in the geographical distribution of the pathogen. Ferreira, Campa and Pérez-Veja (2008) noticed that an extensive geographic distribution of some races might be explained by the presence of the pathogen in seeds.

\section{Virulence index}

The virulence index of $C$. lindemuthianum races ranges from $0 \%$ (no virulence observed in race 0 ) to $66.7 \%$, corresponding to race 479 , which is virulent on eight from the 12 differential cultivars (Figure 2). The 89 races of $C$. lindemuthianum characterized in Brazil were distributed in nine groups based on its virulence index (VI). Besides, two groups are formed by only one race. The first group involves race 0 , which does not cause symptoms on the 12 differential cultivars. Therefore, resistance genes of the differential cultivars (Table 1) can control anthracnose in regions where this race was identified (Paraná and Minas Gerais). The other group formed by only one race contains the race 479 , the most virulent race found in Brazil because it breaks the resistance of Michelite (Co-11), MDRK (Co-1), Perry Marrow (Co-1 $\left.{ }^{3}\right)$, Cornell 49-242 (Co-2), Widusa (Co- $\left.1^{5}\right)$, Mexico 222 (Co-3), PI $207262\left(\mathrm{Co}_{3} 3^{3}\right.$ and $\left.\mathrm{CO}_{-} 4^{3}\right)$ and TO (Co-4). The races 127, 351, and 475 formed a group which has in common overcome the resistance of the following differential cultivars: Michelite (Co-11), MDRK (Co-1), Cornell 49-242 (Co-2), Widusa (Co-15), Mexico 222 (Co-3).

A total of 12 races had a $\mathrm{VI}$ of $16.7 \%$, which can overcome the resistance of two of the 12 differential cultivars. Seventeen races, with a VI of $25 \%$, form one group and can overcome the resistance of three differential cultivars. The $33.3 \% \mathrm{VI}$ group contains 21 races, overcoming the resistance of four differential cultivars. The next group contains 21 races; however, it had a VI of $41.7 \%$, and the members overcame the resistance of five differential cultivars. These data suggest that among the 89 races, 71 overcome the anthracnose resistance genes present in two 
to six differential cultivars.

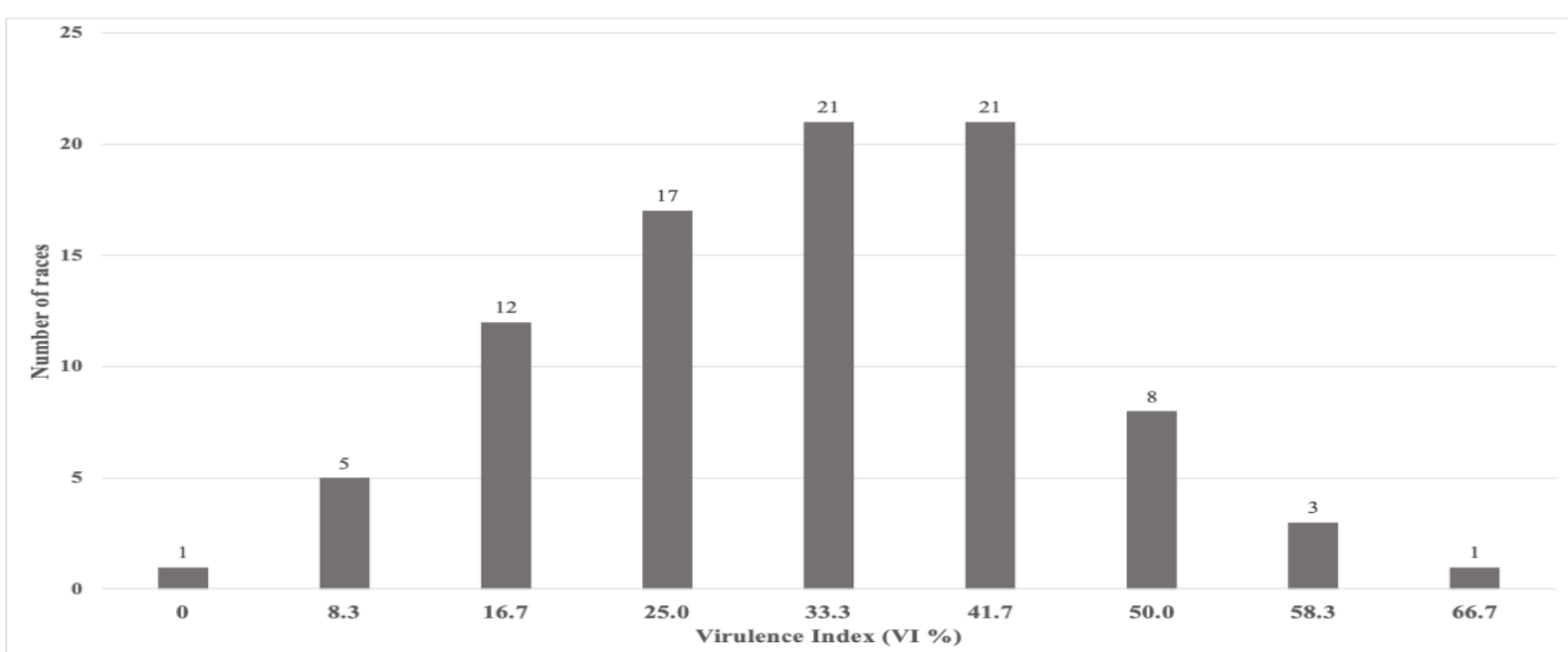

Figure 2. Resistance index of 12 common bean differential cultivars to 89 races of Colletotrichum lindemuthianum characterized in Brazil from 1991 to 2021.

\section{Resistance index and resistance sources}

Figure 3 shows the resistance index (RI) for each of the 12 differential cultivars calculated for the 89 races reported in Brazil from 1991 to 2021. Many races exhibit strong adaptability in regions of high-yield beans. Concerning resistance reactions to the races in Brazil, we observed that the differential cultivars with the most significant resistance index are the Mesoamerican cultivar G 2333 with 100\% resistance to 89 races of the pathogen, followed by $A B 136$ with $98 \%$, TU with 91\%, and PI 207262 with 89\%. Furthermore, six differential cultivars, wherein four are Mesoamerican and two Andean, exhibited high resistance to the 89 races in Brazil of $C$. lindemuthianum noticed across 30 years.

These four Mesoamerican differential cultivars harbor different anthracnose resistance alleles. G 2333, a highly resistant genotype originating from Mexico (Chiapas), contains the resistance alleles $\mathrm{Co}-3^{5}, \mathrm{Co}-4^{2}$, and $\mathrm{Co}-5^{2}$. TU with resistance gene Co-5, AB 136 with Co-6, and PI 207262 with Co-33 and Co-4 are also essential sources of anthracnose resistance worldwide. It is important to emphasize that two Andean differential cultivars, Kaboon and Perry Marrow, display high resistance levels, at $79 \%$ and $63 \%$, respectively. The cultivars Kaboon and Perry Marrow have broad and effective resistance to highly virulent Mesoamerican races. The Andean cultivars Kaboon has the $\mathrm{Co}^{-1} \mathbf{1}^{2}$ allele, and Perry Marrow carries the $\mathrm{Co}-1^{3}$ allele. By studying the resistance reaction of differential cultivars exposed to two essential races of $C$. lindemuthianum (31 and 89), Gonçalves-Vidigal et al. (2001) verified the efficiency of the differential cultivars G 2333, AB 136, and PI 207262, which possess resistance genes that are not compatible with the prevalent races. These authors suggested the use of these cultivars in breeding programs. These cultivars are excellent sources of resistance to anthracnose in other regions (Thomazella et al., 2002; Gonçalves-Vidigal, Thomazella, Vidigal Filho, Kvitschal, \& Elias, 2008). 
The Andean genes $\mathrm{Co}-1^{2}$ (Kaboon), $\mathrm{Co}-1^{4}$ (AND 277), Co-13 (Jalo Listras Pretas), Co-12 (Jalo Vermelho), Co-14 (Pitanga), Co-15 (Corinthiano), Co-Pa (Paloma), Co-AC, (Amendoim Cavalo), Co-Bf (Beija Flor), CoPv01 ${ }^{\text {CDRK }}$ (California Dark Red Kidney); and the Mesoamerican genes $\mathrm{Co}^{4} 3^{4}$ (Ouro Negro), Co-16 (Crioulo 159), Co-5 (TU) Co-3 ${ }^{3}$ and Co-4 (PI 207262), Co-6 (AB 136), Co-3/Co-42/Co- $5^{2}$ (G 2333), and $\mathrm{Co}^{2} 4^{2}$ and Co17 (SEL 1308) are known to confer resistance to most races reported in Brazil and around the world. Thus, pyramiding the genes described above through molecular markers can help reduce the time and cost of introducing commercial common bean cultivars. These single resistance genes are easy to transfer to new commercial cultivars, but there is a risk of overcoming the resistance to new virulence races of $C$. lindemuthianum.

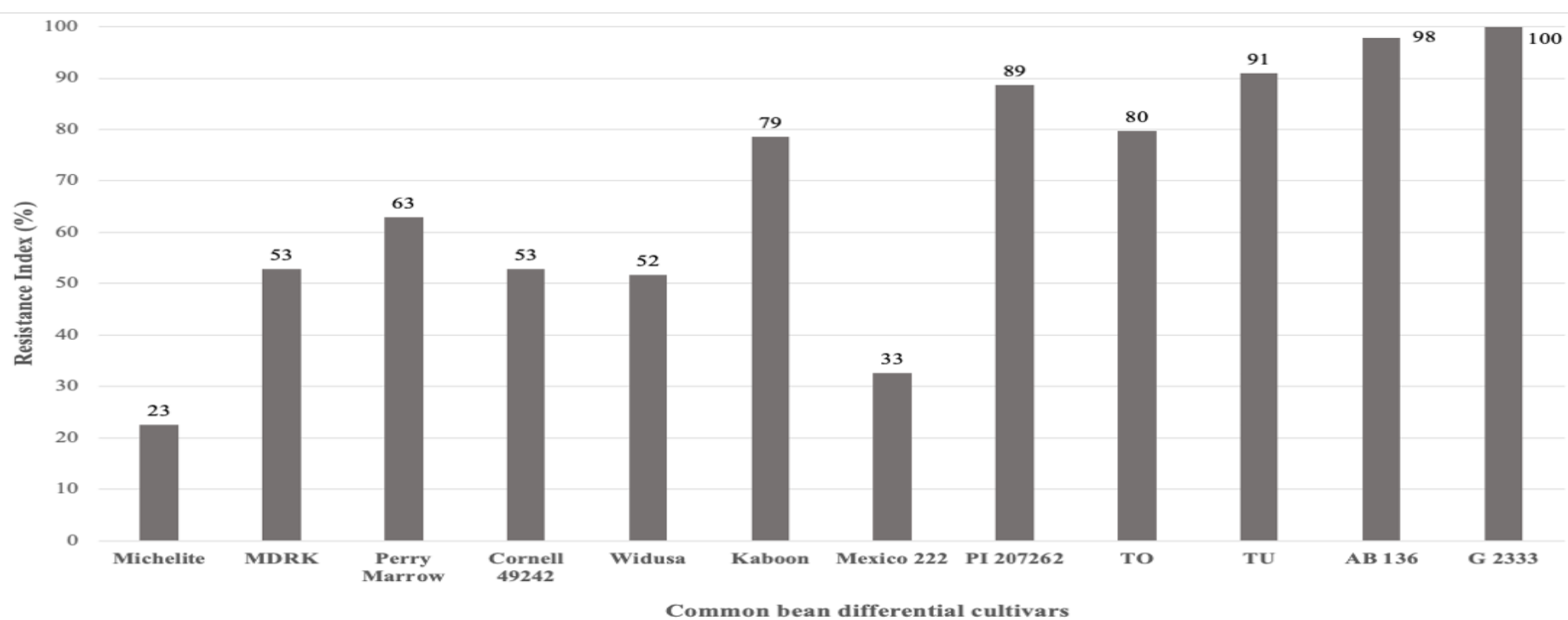

Figure 3. Virulence index of 89 races of Colletotrichum lindemuthianum characterized in Brazil from 1991 to 2021 on 12 common bean differential cultivars.

\section{Outline of sources and resistance genes to Colletotrichum lindemuthianum}

Single and independent genes confer anthracnose resistance in the common bean. Most of these genes have been assigned $\mathrm{Co}$ symbols, as follows: $\mathrm{Co}-1, \mathrm{Co}-2$, Co-3, Co-4, Co-5, Co-6, Co-11, Co-12, Co-13, Co-14, Co-15, Co-16, and Co-17 (Campa, Giraldez, \& Ferreira, 2009; Vallejo \& Kelly, 2009; Gonçalves-Vidigal et al., 2013; Sousa et al., 2014; Sousa et al., 2015; Campa et al., 2014; Lacanallo \& GonçalvesVidigal, 2015; Trabanco, Campa, \& Ferreira, 2015; Zuiderveen, Padder, Kamfwa, Song, \& Kelly, 2016; Coimbra-Gonçalves et al., 2016, Murube, Campa, \& Ferreira, 2019). Additionally, others genes such as Co-u, CoPv02 (Geffroy, Sévignac, Billant, Dron, \& Langin, 2008; Campa et al., 2014), Co-y, Co-z, and Co-RVI were identified. Some of these genes have been mapped using the reference genome developed by Schmutz et al. (2014) and identified candidate genes. Figure 4 shows the positions of molecular markers linked to anthracnose resistance loci with the physical location on chromosomes Pv01, Pv02, Pv03, Pv04, Pv07, Pv08, and Pv11 of the Phaseolus vulgaris reference genome v2.1 (available at https://phytozome.jgi.doe.gov/pz/portal.html). This data is essential to bean breeding programs that seek to broaden the genetic base of the bean crop and to pyramid Andean and Mesoamerican genes conferring resistance to distinct races of 


\section{C. lindemuthianum.}

Molecular markers linked to anthracnose resistance genes have been identified in the last decades. Remarkably, random amplification of polymorphic DNA (RAPD), amplified fragment length polymorphism (AFLP), and restriction fragment length polymorphism (RFLP) markers were followed by sequence characterized amplified region (SCAR), simple sequence repeat (SSR), and singlenucleotide polymorphism (SNP) marker systems (Young, Melotto, Nodari, \& Kelly, 1998; Oblessuc, Francisco, \& Melotto, 2015; Gonçalves-Vidigal et al., 2020). Furthermore, the common bean reference genome (Schmutz et al., 2014) has allowed the mapping and comparing the positions of most SCAR, SSR, and SNP markers (Vaz Bisneta \& Gonçalves-Vidigal, 2020). This section discussed the progress of anthracnose resistance, focusing mainly on genetic mapping studies and molecular markers linked to ANT resistance alleles in the reference genome of the common bean chromosomes Pv01, Pv02 Pv03, Pv04, Pv07, Pv08, Pv11 (Table 3).

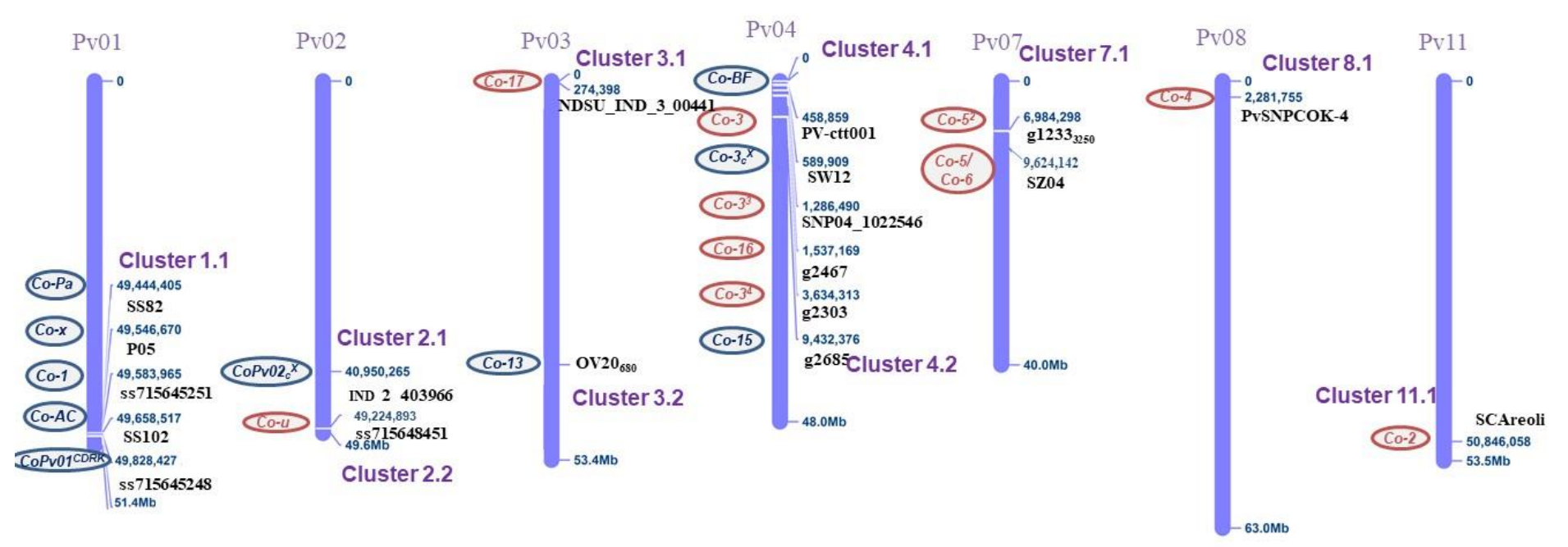

Figure 4. Chromosomal localization of common bean Pv01, Pv02, Pv03, Pv04, Pv07, Pv08, and Pv11 showing the molecular markers tagging ANT resistance loci with their location mapped on the Phaseolus vulgaris on reference genome v2.1 (available at https://phytozome.jgi.doe.gov/pz/portal.html).

\section{Chromosome Pv01}

The Co-1 primary resistance locus and its alleles, such as $\mathrm{CO}^{2} 1^{2}, \mathrm{Co}-1^{3}, \mathrm{Co}-1^{4}$, $\mathrm{CO}_{-} 1^{5}, \mathrm{Co}-1^{\mathrm{HY}}$, and $\mathrm{CO}_{-} 1^{X}$ were mapped in the genomic region of $49,583,965 \mathrm{bp}$ (Gonçalves-Vidigal et al., 2011; Campa et al., 2014; Zuiderveen et al., 2016; Chen et al., 2017; Murube et al., 2019; Melotto \& Kelly, 2000).

As shown in Figure 4, the Andean genes $\mathrm{Co}-\mathrm{x}, \mathrm{CO}-\mathrm{Pa}, \mathrm{CO}-\mathrm{AC}$, and $\mathrm{COPVO}{ }^{\mathrm{CDRK}}$ are located at the end of Pv01 (Gonçalves-Vidigal et al., 2020; Richard et al., 2014; Castro et al., 2017; Gilio et al., 2020). These genes are mapped in the genomic region from $49,444,405$ to $49,828,427 \mathrm{bp}$, indicating that a gene cluster is involved in resistance to many fungal races. Moreover, the Co-AC gene of Amendoim Cavalo was fine-mapped to a 9-kb genomic region at positions between SNP markers SS102 (49,658,517 bp) and SS165 (49,667,961 bp) (Nanami et al., 2017; Gilio et al., 2020). The Andean cultivar California Dark Red Kidney possesses the COPVO1 ${ }^{\text {CDRK }}$ gene flanked by the STS CV542014, and SNP ss715645248 positions 49,795,296 bp 
and 49,828,427 bp of chromosome Pv01, spanning 33 kb (Gonçalves-Vidigal et al., 2020).

Table 3. Common bean anthracnose resistance sources, resistance gene or allele, molecular marker, Phaseolus vulgaris (Pv) chromosome (chr) and position allele was mapped.

\begin{tabular}{|c|c|c|c|c|}
\hline Resistance source & Gene & Molecular Marker & $\begin{array}{l}\mathrm{Pv} \\
\mathrm{chr}\end{array}$ & $\begin{array}{c}\text { Position } \\
\text { v2.1 } \\
\end{array}$ \\
\hline Michelite & Co-11 & & $\mathrm{UM}^{\mathrm{a}}$ & \\
\hline MDRK & Co-1 & ss715645251 & Pv01 & $49,583,965$ \\
\hline Perry Marrow & $\mathrm{Co}-1^{3}$ & ss715645251 & Pv01 & $49,583,965$ \\
\hline Cornell 49242 & $\mathrm{Co}-2$ & SCAreoli & Pv11 & $50,846,058$ \\
\hline Widusa & $\mathrm{Co}-1^{5}$ & ss715645251 & Pv01 & $49,583,965$ \\
\hline Kaboon & $\mathrm{Co}-1^{2}$ & ss715645251 & Pv01 & $49,583,965$ \\
\hline Mexico 222 & Co-3 & PV-ctt001 & Pv04 & 458,859 \\
\hline \multirow{2}{*}{ PI 207262} & $\mathrm{Co}-3^{3}$ & SNP04_1022546 & Pv04 & $1,286,490$ \\
\hline & $\mathrm{Co}-4^{3}$ & PVSNPCOK-4 & Pv08 & $2,281,755$ \\
\hline TO & $\mathrm{Co}-4$ & PvSNPCOK-4 & Pv08 & $2,281,755$ \\
\hline TU & Co-5 & g12333250 & Pv07 & $6,984,298$ \\
\hline AB 136 & Co-6 & SZ04 & Pv07 & $9,624,142$ \\
\hline \multirow{3}{*}{ G 2333} & $\mathrm{Co}-3^{5}$ & SNP04_1022546 & Pv04 & $1,286,490$ \\
\hline & $\mathrm{Co}-5^{2}$ & $\mathrm{~g} 12333_{250}$ & Pv07 & $6,984,298$ \\
\hline & $\mathrm{Co}-4^{2}$ & PVSNPCOK-4 & Pv08 & $2,281,755$ \\
\hline Jalo EEP558 & Co- $x$ & P05 & Pv01 & $49,546,670$ \\
\hline Hongyundou & $\mathrm{Co}-1^{\mathrm{HY}}$ & TF1 & Pv01 & $49,570,786$ \\
\hline Amendoim Cavalo & Co-AC & SS102 & Pv01 & $49,658,517$ \\
\hline CDRK & COPVO1 $1^{\text {CDRK }}$ & ss715645248 & Pv01 & $49,828,427$ \\
\hline AND 277 & $\mathrm{Co}-1^{4}$ & ss715645251 & Pv01 & $49,583,965$ \\
\hline Paloma & $\mathrm{Co}-\mathrm{Pa}$ & SS82 & Pv01 & $49,444,405$ \\
\hline \multirow{3}{*}{ Xana } & $\mathrm{Co}-1^{x}$ & SNP01_483 & Pv01 & $49,512,545$ \\
\hline & CoPv02 $c^{x}$ & IND_2_403966 & Pv02 & $40,950,265$ \\
\hline & $\mathrm{Co}_{0}-3 c^{x}$ & SW12 & Pv04 & 589,909 \\
\hline \multirow{2}{*}{ BAT 93} & Co-u & close to / gene & Pv02 & \\
\hline & $\mathrm{Co}-3^{3}$ & SNP04_1022546 & Pv04 & $1,286,490$ \\
\hline Jalo Vermelho & Co-12 & & UM & \\
\hline Jalo Listras Pretas & $\mathrm{Co}-13$ & OV20 680 & Pv03 & $N A^{b}$ \\
\hline Pitanga & Co-14 & & UM & \\
\hline Corinthiano & Co-15 & g2685 & Pv04 & $9,432,376$ \\
\hline Beija Flor & Co-Bf & & Pv04 & 3,592 \\
\hline Crioulo 159 & Co-16 & g2467 & Pv04 & $1,537,169$ \\
\hline \multirow[t]{2}{*}{ SEL1308 } & $\mathrm{Co}-17$ & NDSU_IND_3_004 & Pv03 & 551,937 \\
\hline & $\mathrm{Co}-4^{2}$ & PvSNPCOK-4 & Pv08 & $2,281,755$ \\
\hline Mexico 227 & $\mathrm{Co}-3^{2}$ & PV-ctt001 & Pv04 & 458,859 \\
\hline Ouro Negro & $\mathrm{Co}-3^{4}$ & g2303 & Pv04 & 3634313 \\
\hline SEL 1360 & $\mathrm{Co}-5^{2}$ & g12333250 & Pv07 & $6,984,298$ \\
\hline MSU7-1 & $\mathrm{Co}-5^{2}$ & g12333 250 & Pv07 & $6,984,298$ \\
\hline
\end{tabular}

aUM, Unmapped resistance gene; ${ }^{b} \mathrm{NA}$, not alligned in the reference genome $\mathrm{v} 2.1$. 


\section{Chromosome Pv02}

The gene Co- $u$ in the cultivar BAT 93 was mapped at the end of Pv02 close to the I locus, conferring resistance to viruses (Geffroy et al., 2008). The Xana cultivar carries the gene $\mathrm{COPvO2} c^{x}$ that was mapped to chromosome Pv02, using the markers IND_2_403966 at the position 40,950,265 bp and IND_2_404411 at 40,981,170 bp (Campa et al., 2014).

\section{Chromosome Pv03}

On chromosome Pv03 have been mapped the resistance genes $\mathrm{CO}_{\mathrm{-}} \mathrm{13}$ and $\mathrm{CO}$ 17 (Lacanallo \& Gonçalves-Vidigal, 2015; Trabanco et al., 2015). Co-13 gene in cultivar Jalo Listras Pretas was mapped at a distance of $1.8 \mathrm{cM}$ of the marker OPV20680, as shown in Figure 4. The Co-17 gene of SEL1308 was mapped to Pv03 at a distance of $9.7 \mathrm{cM}$ from the InDel marker NDSU_IND_3_0.0441 (551,937 bp); this gene also maps to 554,412 bp, linked to the marker B6 (Trabanco et al., 2015).

\section{Chromosome Pv04}

Figure 4 shows the chromosome Pv04 containing the resistance gene $\mathrm{Co}-3$ and its allelic series $\left(\mathrm{CO}^{2} 3^{2}, \mathrm{CO}^{3} 3^{3}, \mathrm{CO}^{3} 3^{4}\right.$, and $\left.\mathrm{CO}^{-} 3^{5}\right)$ as well as $\mathrm{Co}-15$ and $\mathrm{CO}-16$ (Young et al., 1998; Geffroy et al., 1999; Gonçalves-Vidigal et al., 2013; Sousa et al., 2015; Coimbra-Gonçalves et al., 2016). Co-3 present in Mexico 222 is linked to molecular marker PV-ctt001 in the genomic region from 458,859 bp to 459,022 bp (RodríguezSuárez, Ferreira, Campa, Pañeda, \& Giraldez, 2008). Additionally, Co-3³ in BAT 93 was fine-mapped to two regions at the beginning of chromosome 4, from 1,286,490 bp to 1,419,089 bp between markers SNP04_1022546 and SNP04_1308175 and a second region between IND04_10936 (1,908,814 bp) and SNP04_1231633 $(2,047,754 \mathrm{bp})$ markers (Murube et al., 2019). The cultivar Ouro Negro harboring the $\mathrm{Co}-3^{4}$ allele was first mapped to the Pv04, linked to the STS g2303 marker at position 3,634,313 bp (Gonçalves-Vidigal et al., 2013). Co-16 in Crioulo 159 is linked to the marker g2467 $900 / 800$ mapped to the position of $1,537,169$ bp on Pv04 (Coimbra-Gonçalves et al., 2016). Moreover, the Andean cultivar Corinthiano carries the independent gene $\mathrm{Co}-15$ linked to the sequence-tagged site (STS) marker g2685 on Pv04, at 9,432,376 bp (Sousa et al., 2015).

\section{Chromosome Pv07}

The Mesoamerican cultivars TU, SEL 1360, G 2333, MSU-7, AB 136 carry resistance genes conferring resistance to different races of $C$. lindemuthianum mapped on chromosome PV07 in Figure 4. The TU cultivar exhibits resistance to races $3,6,7,31,38,39,102$, and 449 in a cluster that appears to correspond to Co5 (Campa et al., 2009). A second allele, Co- $5^{2}$, is present in cultivars $\mathrm{G} 2333$ and MSU-7. The different resistance spectra between TU and G 2333 present another allele in G 2333, renaming it Co-5² (Vallejo \& Kelly, 2009).

As shown Figure 4 , the $\mathrm{Co}^{-5^{2}}$ resistance allele, which confers resistance to Race 64 of $C$. lindemuthianum, is also present in MSU 7-1 and linked to the marker g1233 3250 region from 6,984,298 bp to 7,020,710 bp (Sousa et al., 2014). The gene Co-6 present in AB 136 confers resistance to races $23,31,64,65,69,453$, and 449 linked to the marker SZ04 at position 9,624,142 Pv07 (Campa et al., 2017). 


\section{Chromosome Pv08}

G 2333 carries three resistance genes. The major one is $\mathrm{Co}^{2} \mathbf{4}^{2}$ (Young et al., 1998; Silvério et al., 2002). Mesoamerican resistance gene Co-4 and its alleles (Co$4^{2}$ and $\left(\mathrm{O}-4^{3}\right)$ have been mapped from 2,281,755 to 2,301,726 on Pv08. Although the RAPD OAS13950 and SAS13 markers have been linked to resistance genes in TO (Co-4) and G $2333\left(\mathrm{Co}^{2} 4^{2}\right)$, they are absent in control (susceptible) cultivars (Young et al., 1998). The allele $\mathrm{Co}-4^{2}$ is present in SEL 1308, a cultivar derived from $\mathrm{G}$ 2333. Studies of the fine mapping of $\mathrm{Co}-4$ have been conducted by cloning the gene sequence associated with the SAS13 marker, linked to Co-4 at $0.39 \mathrm{cM}$ (Melotto \& Kelly, 2001). Oblessuc et al. (2015) mapped the Co-4 locus in a 325-kb region adjacent to the telomere of Pv08 containing the markers SAS13, PvTA25, and PvSPICK-4. Mesoamerican $\mathrm{Co}-4^{2}$ anthracnose resistance allele confers resistance to all races of the anthracnose pathogen in Brazil.

\section{Chromosome Pv11}

The cultivar Cornell 49-242 possesses the Co-2 gene, one of the essential ANT resistance genes linked to SCAreoli from 50,846,058 bp to 50,925,118 bp of Pv11 (Kelly \& Young, 1996; Geffroy et al., 1998). Cornell 49-242, from Venezuela, was widely used in breeding programs in the 1970s. Nevertheless, the continuous use of cultivars carrying the $\mathrm{Co}-2$ gene led to host-pathogen coevolution and the appearance of new races able to overcome the resistance due to Co-2 (Kelly \& Vallejo, 2004).

\section{C. lindemuthianum and Phaseolus vulgaris L. coevolution}

Andean races of the anthracnose pathogen are usually isolated from largeseeded beans that belong to the Andean gene pool. In contrast, Mesoamerican races are often, but not always, isolated from small or medium-seeded beans belonging to the Mesoamerican gene pool-the Mesoamerican races of the fungus exhibit considerably greater virulence genetic diversity than the Andean races (Pastor-Corrales, 2004; Kelly \& Vallejo, 2004). More importantly, the Andean races are compatible only or mainly with Andean beans. In contrast, Mesoamerican races are compatible with both Mesoamerican and Andean beans. Also, anthracnose resistance loci from Mesoamerican beans are significant for controlling Andean races (Kelly \& Vallejo, 2004).

It has been posited that the Andean and Mesoamerican races of $C$. lindemuthianum have evolved separately. The wide virulence reported in this review suggests that knowing the diversity of the $C$. lindemuthianum pathogen of the common bean is an actual effort to assist breeders in developing cultivars with effective and hopefully durable anthracnose resistance. Anthracnose Andean resistance genes might be used to manage anthracnose disease in areas where Mesoamerican races are more common than the Andean races. Furthermore, sources of resistance to anthracnose of Mesoamerican origin might manage Andean races. Combining several genes in a single cultivar should be helpful to achieve durable resistance to the highly variable pathogen that causes anthracnose in the common bean. 


\section{FINAL COMMENTS}

In this report, we noticed that C. lindemuthianum is widely distributed and adapted to different bean-growing regions in Brazil. Herein we reported 30 years of C. lindemuthianum diversity in Brazil. The data shown in this study can help breeding programs to develop common bean cultivars resistant to anthracnose in Brazil. Excellent opportunities for rapid and efficient development of molecular markers tightly linked to resistance genes can be obtained due to the accessibility to complete common bean genome sequence. Herein, information on identified anthracnose resistance genes can be found with the genome position, facilitating marker-assisted selection. In the future, resources should propitiate better marker systems such as KASP, SSRs, and SNPs for the fungus population structure studies. The wide virulence reported in this review suggests that knowing the diversity of the $C$. lindemuthianum pathogen of the common bean is a real effort to assist breeders in developing cultivars with effective and hopefully durable anthracnose resistance.

The availability of genomic information is significant while breeding for resistance is gaining considerable attention, and gene pyramiding represents an ambitious challenge for breeding programs to achieve durable resistance. The ease of using a complete genome sequence of common bean offers many opportunities for the rapid and efficient development of molecular markers tightly linked to resistance genes. The knowledge of specific races of $C$. lindemuthianum in each state of Brazil and the understanding of disease resistance alleles with molecular markers and position in the bean genome will assist the bean breeder and facilitate marker-assisted use selection. The aspects discussed in this review contribute to knowledge that may be helpful for common bean breeding programs focused on developing cultivars resistant to anthracnose.

\section{ACKNOWLEDGEMENTS}

This research was financially supported by the National Council for Scientific and Technological Development (CNPq). P.P.S. Paulino, M., Vaz Bisneta, G. Valentini, L.F.S. Xavier, and M.P.B.A. Nunes were supported by a Scholarship from Capes. M. C. Gonçalves-Vidigal and P. S. Vidigal Filho are grateful for Grants from CNPq.

\section{REFERENCES}

Alzate-Marin, A. L., \& Sartorato, A. (2004). Analysis of the pathogenic variability of Colletotrichum lindemuthianum in Brasil. Annual Report of the Bean Improvement Cooperative, 47, 241-242.

Awale, H. E., Bornowski, N., Wright, E. M., Varner, G. V., \& Kelly, J. D. (2018). Characterization and distribution of a new emerging race of anthracnose in Michigan. Annual Reporter Bean Improvement Cooperative, 61, 113-114.

Balardin, R. S. Pastor-Corrales, M. A., \& Otoya, M. M. (1990). Variabilidade patogênica de Colletotrichum lindemuthianum no estado de Santa Catarina. Fitopatologia Brasileira, 15, 243-245. 
Balardin, R. S, Jarosz, A. M., \& Kelly, J. D. (1997). Virulence and molecular diversity in Colletotrichum lindemuthianum from South, Central and North America. Phytopathology, 87 , 1184-1191. https://doi.org/10.1094/PHYTO.1997.87.12.1184

Balardin, R. S., \& Kelly, J. D. (1998). Interaction between Colletotrichum lindemuthianum races and gene pool diversity in Phaseolus vulgaris. Journal of the American Society for Horticultural Science, 123, 1038-1047. https://doi.org/10.21273/JASHS.123.6.1038

Barcelos, Q. L., Souza, E. A., \& Silva, K. J. D. (2011). Vegetative compatibility and genetic analysis of Colletotrichum lindemuthianum isolates from Brazil. Genetics and Molecular Research, 10, 230-242. https://doi.org/10.4238/vol10$1 \mathrm{gmr} 907$

Bitocchi, E., Rau, D., Bellucci, E., Rodriguez, M., Murgia, M. L., Gioia, T., Santo, D., Nanni, L., Attene, G., \& Papa, R. (2017). Beans (Phaseolus ssp.) as a model for understanding crop evolution. Frontiers in Plant Science, 8, 1-21. https://doi.org/10.3389/fpls.2017.00722

Campa, A., Giraldez, R., \& Ferreira, J. J. (2009). Genetic dissection of the resistance to nine anthracnose races in the common bean differential cultivars MDRK and TU. Theoretical and Applied Genetics, 119, 1-11. https://doi.org/10.1007/s00122-009-1011-8

Campa, A., Rodríguez-Suárez, C., Giraldez, R., \& Ferreira, J. J. (2014). Genetic analysis of the response to eleven Colletotrichum lindemuthianum races in a RIL population of common bean (Phaseolus vulgaris L.). BMC Plant Biology, 14, 115. https://doi.org/10.1186/1471-2229-14-115

Campa, A., Trabanco, N., \& Ferreira, J. J. (2017). Identification of clusters that condition resistance to anthracnose in the common bean differential cultivars AB 136 and MDRK. Phytopathology, 107, 1515-1521. https://doi.org/10.1094/PHYTO-01-17-0012-R

Carneiro, S.M.T.P.G. (1999). Raças fisiológicas de Colletotrichum lindemuthianum no estado do Paraná. Summa Phytopathologica, 25, 275-278.

Carvalho, L. M. J., Corrêa, M. M., Pereira, E. J., Nutti, M. R., Carvalho, J. L. V., Ribeiro, E. M. G., \& Freitas, S. C. (2012). Iron and zinc retention in common beans (Phaseolus vulgaris L.) after home Cooking. Food \& Nutrition Research, 56, 15618. https://doi.org/10.3402/fnr.v56i0.15618

Castro, S. A. L., Gonçalves-Vidigal, M. C., Gilio, T. A. S., Lacanallo, G. F., Valentini, G., Martins, V. S. R., Song, Q., Galván, M. Z., Hurtado-Gonzales, O. P., \& PastorCorrales, M.A. (2017). Genetics and mapping of a new anthracnose resistance locus in Andean common bean Paloma. BMC Genomics, 18, 306. https://doi.org/10.1186/s12864-017-3685-7 
Chen, M., Wu, J., Wang, L., Mantri, N., Zhang, X., Zhu, Z., \& Wang, S. (2017). Mapping and genetic structure analysis of the anthracnose resistance locus Co$1^{\text {HY }}$ in the common bean (Phaseolus vulgaris L.). PLoS ONE, 12(1). https://doi.org/10.1371/journal.pone.0169954

Coêlho, M., Gonçalves-Vidigal, M. C., Vidigal Filho, P. S., Franzon, R. C., \& Martins, V. S. R. (2020) Genetic diversity of Colletotrichum lindemuthianum races based on ITS-rDNA regions. Agronomy Science and Biotechnology, 6, 1-18. https://doi.org/10.33158/ASB.r112.v6.2020

Coimbra-Gonçalves, G. K., Gonçalves-Vidigal, M. C., Coelho, R. T., Valentini, G., Vidigal Filho, P. S., Lacanallo, G. F., Sousa, L. L., \& Elias, H. T. (2016). Characterization and mapping of anthracnose resistance gene in Mesoamerican common bean cultivar Crioulo 159. Crop Science, 56, 1-12. https://doi.org/10.2135/cropsci2015.10.0651

CONAB - Companhia nacional de abastecimento. (2019). Retrieved Dez 102019. http://www.conab.gov.br

FAO - Food and Agriculture Organization. (2019). Faostat database gateway. Retrieved 12 2019. http://www.fao.org

Felipin-Azevedo, R., Gonçalves-Vidigal, M. C., Lacanallo, G. F., Souza, M. C. M., Castro, S. A. L., Caixeta, M. P., \& Vidigal Filho, P. S. (2014). Analysis of diverse Colletotrichum lindemuthianum isolates of common bean (Phaseolus vulgaris $\mathrm{L}$.) from Mato Grosso State, Brazil. Annual Report of the Bean Improvement Cooperative, 57, 143-144.

Ferreira, J. J., Campa, A., \& Pérez-Veja, E. (2008). Reaction of a bean germplasm collection against five races of Colletotrichum lindemuthianum Identified in Northern Spain and implications for breeding. Plant Disease, 92, 705-708. https://doi.org/10.1094/PDIS-92-5-0705

Geffroy, V., Creusot, F., Falquet, J., Sevignac, M., Adam-Blondon, A. F., Bannerot, H., Gepts, P., \& Dron, M. (1998). A family of LRR sequences in the vicinity of the Co2 locus for anthracnose resistance in Phaseolus vulgaris and its potential use in marker-assisted selection. Theoretical and Applied Genetics, 96, 494502. https://doi.org/10.1007/s001220050766.

Geffroy, V., Sévignac, M., Billant, P., Dron, M., \& Langin, T. (2008). Resistance to Colletotrichum lindemuthianum in Phaseolus vulgaris: a case study for mapping two independent genes. Theoretical and Applied Genetics, 116, 407-415. https://doi.org/10.1007/s00122-007-0678-y

Geffroy, V., Sicard, D., Oliveira, J. C. F., Sévignac, M., Cohen, S., Gepts, P., Neema, C., Langin, T., \& Dron, M. (1999). Identification of an ancestral resistance gene cluster involved in the coevolution process between Phaseolus vulgaris and its fungal pathogen Colletotrichum lindemuthianum. Molecular Plant-Microbe Interactions Journal, 12, 774-784. https://doi.org/10.1094/mpmi.1999.12.9.774 
Gilio, T. A. S., Hurtado-Gonzales, O. P., Gonçalves-Vidigal, M. C., Valentini, G., Elias J. C. F., Song, Q., \& Pastor-Corrales, M. A. (2020). Fine mapping of an anthracnose-resistance locus in Andean common bean cultivar Amendoim Cavalo. PLOS ONE , 15(10). https://doi.org/10.1371/journal.pone.0239763

Gonçalves-Vidigal, M. C., Cruz, A. S., Garcia, A., Kami, J., Vidigal Filho, P. S., Sousa, L. L., ... \& Pastor-Corrales, M. A. (2011). Linkage mapping of the Phg-1 and Co$1^{4}$ genes for resistance to angular leaf spot and anthracnose in the common bean cultivar AND 277. Theoretical and Applied Genetics, 122, 893903. https://doi.org/10.1007/s00122-010-1496-1

Gonçalves-Vidigal, M. C., Cruz, A. S., Lacanallo, G. F., Vidigal Filho, P. S., Sousa, L. L., Pacheco, C. M. N. A., Mc Clean, P., Gepts, P., \& Pastor-Corrales, M. A. (2013). Co-segregation analysis and mapping of the anthracnose $\mathrm{Co}-10$ and angular leaf spot Phg-ON disease-resistance genes in the common bean cultivar Ouro Negro. Theoretical and Applied Genetics, 126, 2245-2255. https://doi.org/10.1007/s00122-013-2131-8l

Gonçalves-Vidigal, M. C., Gilio, T. A. S., Valentini, G., Vaz-Bisneta, M., Vidigal Filho, P. S., Song, Q., Oblessuc, P., \& Melotto, M. (2020). New Andean source of resistance to anthracnose and angular leaf spot: Fine-mapping of diseaseresistance genes in California Dark Red Kidney common bean cultivar. PLoS ONE , 15(6). https://doi.org/10.1371/journal.pone.0235215

Gonçalves-Vidigal, M. C., Nunes, M. P., Cruz, A. S., Sousa, L. L., \& Vidigal Filho, P. S. (2009). Characterization of Colletotrichum lindemuthianum isolates from Mato Grosso State, Brazil. Annual Reporter Bean Improvement Cooperative, 52, 5253.

Gonçalves-Vidigal, M. C., Sakiyama, N. S., Vidigal Filho, P. S., Amaral Júnior, A. T., Poletine, J. P., \& Oliveira, V. R. (2001). Resistance of Common Bean Cultivar AB 136 to Races 31 and 69 of Colletotrichum lindemuthianum: the Co-6 locus. Crop Breeding and Applied Biotechnology, 1, 99-104. https://doi.org/10.13082/19847033.v01n02a01

Gonçalves-Vidigal, M. C., Thomazella, C., Vidigal Filho, P. S., Kvitschal, M. V., \& Elias, H. T. (2008). Characterization of Colletotrichum lindemuthianum isolates using differential cultivars of common bean in Santa Catarina State, Brazil. Brazilian Archives of Biology Technology, 51, 883-888. https://doi.org/10.1590/S151689132008000500002

Ishikawa, F. H., Souza, E. A., Silva, K. J. D., \& Freire, C. N. S. (2008). Pathogenic variability of causal agent of common bean anthracnose. Annual Report of the Bean Improvement Cooperative, 51, 183-185.

Kelly, J. D., Awale, H., \& Wiersma, A. (2020). Status of anthracnose in Michigan in 2020. Annual Reporter Bean Improvement Cooperative, 63, 113 -114.

Kelly, J. D., \& Young, R.A. (1996) Proposed symbols for anthracnose resistance genes. Annual Reporter Bean Improvement Cooperative, 39, 20-24. 
Kelly, J. D., Gepts, P., Miklas, P. N., \& Coyne, D. P. (2003). Tagging and mapping of genes and QTL and molecular marker-assisted selection for traits of economic importance in bean and cowpea. Field Crops Research, 82, 135-154. https://doi.org/10.1016/S0378-4290(03)00034-0

Kelly, J. D., \& Vallejo V. A. (2004). A comprehensive review of the major genes conditioning resistance to anthracnose in common bean. HortScience, 39, 1196207. https://doi.org/10.21273/HORTSCI.39.6.1196

Lacanallo, G. F., \& Gonçalves-Vidigal, M. C. (2015). Mapping of an Andean gene for anthracnose resistance (Co-13) in common bean (Phaseolus vulgaris L.) Jalo Listras Pretas landrace. Australian Journal of Crop Science, 9, 394-400. https://doi.org/10.2135/cropsci2008.01.0004

Martiniano-Souza, M. C., Gonçalves-Vidigal, M. C., Costa, A. F., Vidigal Filho, P. S., Martins, V. R., Vaz Bisneta, M., Lacanallo, G. F., Coelho, M., Dartibale, G. B., \& Valentini, G. (2021). Virulence and genetic diversity of Colletotrichum lindemuthianum and resistance of local common bean germplasm to anthracnose in Pernambuco State, Brazil. European Journal of Plant Pathology, 159, 727-740. https://doi.org/10.1007/s10658-020-02179-3

Melotto, M., \& Kelly, J. D. (2000). An allelic series at the Co-1 locus conditioning resistance to anthracnose in common bean of Andean origin. Euphytica, 116, 143-149. https://doi.org/10.1023/a:1004005001049

Melotto, M., \& Kelly, J. D. (2001). Fine mapping of the Co-4 locus of common bean reveals a resistance gene candidate, COK-4, that encodes for a protein kinase. Theoretical and Applied Genetics, 103, 508-517. https://doi.org/10.1007/s001220100609

Mesquita, A. G. G., Paula Júnior, T. J., Moreira, M. A., \& Barros, E. G. (1998). Identification of races of Colletotrichum lindemuthianum with the aid of PCR based molecular markers. Plant Disease, 82, 1084-1087. https://doi.org/10.1094/PDIS.1998.82.10.1084

Murube, E., Campa, A., \& Ferreira, J. J. (2019). Integrating genetic and physical positions of the anthracnose resistance genes described in bean chromosomes Pv01 and Pv04. PLOS ONE , 14(2). https://doi.org/10.1371/journal.pone.0212298

Nanami, D. S. Y., Gonçalves-Vidigal, M. C., Castro, S. A. L., Frias, A. A. T., Vidigal Filho, P. S., \& Elias, H. T. (2017). Characterization of genetic resistance in Andean common bean cultivar Amendoim Cavalo to Colletotrichum lindemuthianum. Agronomy Science and Biotechnology, 3(1), 43. https://doi.org/10.33158/asb.2017v3i1p43

Oblessuc, P. R., Francisco, C., \& Melotto, M. (2015). The Co-4 locus on Chromosome Pv08 contains a unique cluster of 18 COK-4 genes and is regulated by immune response in common bean. Theoretical and Applied Genetics, 128, 1193-1208. https://doi.org/10.1007/s00122-015-2500-6 
Pacheco, L. M., Berrouet, K. V., Yepes, M. S., Sánchez, P. G., \& Montoya, M. M. (2014). Detección por PCR de Colletotrichum lindemuthianum en cultivos y semillas de frijol en Antioquia, Colombia. Acta Agronómica, 63, 377-387. https://doi.org/10.15446/acag.v63n4.42035

Pastor-Corrales, M.A. (1991). Estandarización de cultivares diferenciales y de designación de razas de Colletotrichum lindemuthianum. Phytopathology, 81, 694.

Pastor-Corrales, M. A. (2004). Review of coevolution studies between pathogens and their common bean hosts: implication for the development of diseaseresistant beans. Annual Reporter Bean Improvement Cooperative, 47, 67-68.

Perilla, H. E. R., Cirino, V. M., Ruas, P. M., Pavan, M. A., \& Gonçalves, E. S. A. (2015). Phosphorus acquisition and use efficiency in bean cultivars of the "Carioca" and "Preto" commercial groups. Agronomy Science and Biotechnology, 1(1), 33. https://doi.org/10.33158/asb.2015v1i1p33

Pinto, J. M. A., Pereira, R., Mota, S. F., Ishikawa, F. H., \& Souza, E. A. (2012). Investigating phenotypic variability in Colletotrichum lindemuthianum populations. Phytopathology, 102, 490-497. https://doi.org/10.1094/PHYTO06-11-0179

Rava, C. A., Purchio, A. F., \& Sartorato, A. (1994). Caracterização de patótipos de Colletotrichum lindemuthianum que ocorrem em algumas regiões produtoras de feijoeiro comum. Fitopatologia Brasileira, 19, 167-172.

Ribeiro, T., Esteves, J. A. F., Silva, D. A., Gonçalves, J. G. R., Carbonell, S. A. M., \& Chiorato, A. F. (2016). Classification of Colletotrichum lindemuthianum races in differential cultivars of common bean. Acta Scientiarum Agronomy, 38, 179184. https://doi.org/10.4025/actasciagron.v38i2.27866

Richard, M. M. S., Pflieger, S., Sevignac, M., Thareau, V., Blanchet, S., Li, Y., Jackson, S. A., \& Geffroy, V. (2014). Fine mapping of Co-X, an anthracnose resistance gene to a highly virulent strain of Colletotrichum lindemuthianum in common bean. Theoretical and Applied Genetics, 127, 1653-1666. https://doi.org/ 10.1007/s00122-014-2328-5

Rodríguez-Suárez, C., Ferreira, J. J., Campa, A., Pañeda, A., \& Giraldez, R. (2008). Molecular mapping and intra-cluster recombination between anthracnose racespecific resistance genes in the common bean differential cultivars Mexico 222 and Widusa. Theoretical and Applied Genetics, 116, 807-814. https://doi.org/10.1007/s00122-008-0714-6

Sansigolo, A., Gonçalves-Vidigal, M. C., Vidigal Filho, P. S., Gonela, A., \& Kvitschal, M. V. (2008). New races of Colletotrichum lindemuthianum in common bean (Phaseolus vulgaris L.) in Paraná State, Brazil. Annual Report of the Bean Improvement Cooperative, 51, 192-193. 
Schmutz, J., McClean, P. E., Mamidi, S., Wu, G. A., Cannon, S. B., Grimwood, ... \& Jackson, S. A. (2014). A reference genome for common bean and genome-wide analysis of dual domestications. Nature Genetics, 46, 707-713. https://doi.org/10.1038/ng.3008

Silva, K. J. D., Souza, E. A., Sartorato, A., \& Ishikawa, F. H. (2007). Characterization of Colletotrichum lindemuthianum isolates from the State of Minas Gerais, Brazil. Journal of Phytopathology, 155, 241-247. https://doi.org/10.1111/j.14390434.2007.01226.x

Silvério, L., Gonçalves-Vidigal, M. C., Vidigal Filho, P. S., Barelli, M. A. A., Thomazella, C., \& Nunes, W. M. C. (2002). Genetic resistance to Colletotrichum lindemuthianum to race 2047 in G 2333. Annual Report of the Bean Improvement Cooperative, 45, 74-75.

Singh, S. P., \& Schwartz, H. F. (2010). Breeding common bean for resistance to diseases: a review. Crop Science, 50, 2199-2223. https://doi.org/10.2135/cropsci2009.03.0163

Somavilla, L. L., \& Prestes, A. M. (1999). Identificação de patótipos de Colletotrichum lindemuthianum de algumas regiões produtoras de feijão do Rio Grande do Sul. Fitopatologia Brasileira, 24, 416-421.

Sousa, L. L., Cruz, A. S., Vidigal Filho, P. S., Vallejo, V. A., Kelly, J. D., \& GonçalvesVidigal, M. C. (2014). Genetic mapping of the resistance allele Co-52 to Colletotrichum lindemuthianum in the common bean MSU 7-1 line. Australian Journal of Crop Science, 8, 317-323.

Sousa, L. L., Gonçalves, A. O., Gonçalves-Vidigal, M. C., Lacanallo, G. F., Fernandez, A. C., Awale, H., \& Kelly, J. D. (2015). Genetic characterization and mapping of anthracnose resistance of common bean landrace cultivar Corinthiano. Crop Science, 55, 1-11. https://doi.org/10.2135/cropsci2014.09.0604

Talamini, V., Souza, E. A. Pozza, E. A., Carrijo, F. R. F., Ishikawa, F. H., Silva, K. J. D., \& Oliveira, F. A. (2004). Identificação de raças patogênicas de Colletotrichum lindemuthianum a partir de isolados provenientes de regiões produtoras de feijoeiro comum. Summa Phytopathologica, 30, 371-375.

Thomazella, C., Gonçalves-Vidigal, M. C., Vidigal Filho, P. S., Nunes, W. M. C., \& Vida, J. B. (2002). Characterization of Colletotrichum lindemuthianum races in Paraná state, Brazil. Crop Breeding and Applied Biotechnology, 2, 55-60.

Trabanco, N., Campa, A., \& Ferreira, J. J. (2015). Identification of a new chromosomal region involved in the genetic control of resistance to anthracnose in common bean. The Plant Genome, 8, 1-11. https://doi.org/10.3835/plantgenome2014.10.0079

Uchôa, E. B, Gonçalves-Vidigal, M. C., Souza, M. C. M., Vidigal Filho, P. S., Castro, S. A. L., \& Poletine, J. P. (2015). New races of Colletotrichum lindemuthianum in common bean from Parana State, Brazil. Annual Report of the Bean Improvement Cooperative, 58, 41-42. 
Vallejo, V., \& Kelly, J. D. (2009). New Insights into the anthracnose resistance of common bean landrace G 2333. The Open Horticulture Journal, 2, 29-33.

Vaz Bisneta, M., \& Gonçalves-Vidigal, M. C. (2020). Integration of anthracnose resistance loci and RLK and NBS-LRR-encoding genes in the Phaseolus vulgaris $\mathrm{L}$. genome. Crop Science, 60, 2901-2918. https://doi.org/10.1002/csc2.20288

Vidigal Filho, P. S., Gonçalves-Vidigal, M. C., Kelly, J.D., \& Kirk, W. W. (2007). Sources of resistance to anthracnose in traditional common bean cultivars from Parana, Brazil. Journal of Phytopathology, 155, 108-113. https://doi.org/10.1111/j.1439-0434.2007.01203.x

Voorrips, R. E. (2002). MapChart: Software for the graphical presentation of linkage maps and QTLs. Journal of Heredity, 93, 77-78. https://doi.org/10.1093/jhered/93.1.77

Wendland, A., Abud, R. O. G., Melo, L. C., Pereira, H. S., \& Díaz, J. L. C. (2011). Intraspecific variability of Colletotrichum lindemuthianum. Annual Report of the Bean Improvement Cooperative, 54, 108-109.

Xavier, L. F. S., Poletine, J. P., Vidigal Filho, P. S., Martiniano-Souza, M. C., Calvi, A. C., Castro, S. A. L., Silva, J. B., Dartibale, G. B., \& Gonçalves-Vidigal, M. C. (2018). Races of Colletotrichum lindemuthianum in common bean from Paraná state, southern of Brazil. Annual Report of the Bean Improvement Cooperative, 61, 107-108.

Young, R. A., Melotto, M., Nodari, R. O., \& Kelly, J. D. (1998). Marker-assisted dissection of the oligogenic anthracnose resistance in the common bean cultivar "G2333". Theoretical and Applied Genetics, 96, 87-94. https://doi.org/10.1007/s001220050

Zuiderveen, G. H., Padder, B. A., Kamfwa, K., Song, Q., \& Kelly, J. D. (2016). Genome-wide association study of anthracnose resistance in Andean beans (Phaseolus vulgaris). PLoS ONE, 11: e0156391. https://doi.org/10.1371/journal.pone.0156391 